\title{
HISTORY
}

\section{THE HISTORICAL TRACES OF ANCIENT SUMERIAN LANGUAGE IN DIALECT LEXIS OF AZERBAIJAN AND TURKISH LANGUAGE}

\author{
Phil. PhD. Assistant Professor Galiba Hajiyeva \\ Nakhchivan State University
}

DOI: https://doi.org/10.31435/rsglobal_ijitss/30112019/6821

\section{ARTICLE INFO}

Received 22 September 2019

Accepted 18 November 2019

Published 30 November 2019

\section{KEYWORDS}

Sumerian language,

Azerbaijan,

Turkish,

Nakhchivan,

Eastern Anatoly,

Orhon inscriptions,

dialect.

\begin{abstract}
National affiliation of ancient Sumerian language is one of problematic problems create serious conflict in the world linguistics. These are the serious fact putan end to conflicts modern Turkic languages ancient Sumerian and dialect of the comparative investigation. The historical dialectological facts is shows being specific place all-Turkish languages and dialects between the dialects of Nakhchivan and Eastern Anatoly. The efficient situation in the dialects modern Nakhchivan and Eastren Anatolyan dialects is one of defining basic factors of the ancient Sumerian language Orhon inscriptions, eposes of the "Kitabi Dede Korkut", in the İbn Muhenna dictionary, in the "Oğuzname", in the work "Divany lugat-it Türk", of the Turkish folk-lore, the century XIX of the literary works and modern Turk dialects classic until words developed is one of defining basic factors position the between all-Turkish dialect and dialects of the Nakhchivan and Eastren Anadolyan dialects. The comparison Sumerian language of the Nakhchivan and Eastern Anatolyan dialects is being affirms of the dictionaries prepared on the basis of the ancient Turkish language.

The phonetic, lexical facts be reflected of the ancient Sumerian language in the works Sturtevantin "A Hittite Glossory ve Suppelment to a Hittite Glossary" and the work "The historical connection of the Sumer and Turkic languages by about age of the Turkish" Osman Nedim Tuna's, "The Sumerian language is decisively the Turkish" and the work A.Caliloğlu's to work according to with elucidating passed up to this day and the comparison Nakhcivan and Anatolyan dialects affirms being the most ancient language of the Turkish. Many words in the ancient Sumerian language involves for the attention by the same phonetic composition and semantic meaning adjoining by dialects of Nakhchivan and Anatoly dialects by words in the language of the other ancient Turk monuments: yağı, yu, kul, yığın, yig, çağa, çak, köğüs, gid, fani, yogun, qalın, tügün, bağlam,

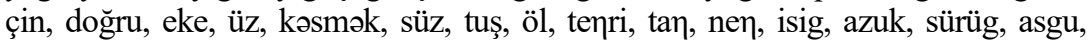
kapkacak, kaç, kuru, neme, korı, toku, togıra, dengüş, zevzek, dingilde, cengel, qaqa//qağa, gim, kalı, ku, öbür and other. The interesting side like is involves for the attention in Sumerian language for instance, kidık/kidik qidiyh koduk, kuzu, köşək, küçük of the animal names develop in the Nakhchivan and Anatoly dialects.
\end{abstract}

Citation: Galiba Hajiyeva. (2019) The Historical Traces of Ancient Sumerian Language in Dialect Lexis of Azerbaijan and Turkish Language. International Journal of Innovative Technologies in Social Science. 8(20). doi: 10.31435/rsglobal_ijitss/30112019/6821

Copyright: (C) 2019 Galiba Hajiyeva. This is an open-access article distributed under the terms of the Creative Commons Attribution License (CC BY). The use, distribution or reproduction in other forums is permitted, provided the original author(s) or licensor are credited and that the original publication in this journal is cited, in accordance with accepted academic practice. No use, distribution or reproduction is permitted which does not comply with these terms.

Linguistic researches carried out on an ancient Sumerian language which is considered the first graphical language confirms the current Turkish language to be the most ancient graphical language among the world languages. Sumerian language was spoken in Eastern Mesopotamia 4000 years ago and was 
replaced with Acadian language at the beginning of 2000s B.C. as a spoken language, and was further used as a scientific and literary language in Mesopotamia up to I century A.D.

Further this language was forgotten until the XIX century. Up to recent time relationship of Sumerian language with any ancient and modern world languages was not confirmed completely, however phonomorphological parallelity between lexical system of the ancient Sumerian and modern Turkic languages, as well as their dialects in comparative researches indicate that Turkish language is an heir of the Sumerian language.

Although national ownership of the ancient Sumerian language is one of the problematic issues causing disputes in the world linguistics, the most serious fact ending these debates is the language facts emerging at the result of comparison of modern Turkic languages and dialects. Linguistic researches of the recent years show that from lexical and grammatical aspects Sumerian language has the phonomorphological structure similar to modern Turkic languages. (1, p. 307).

According to scientific world, ancient Sumerian, as a language isolated from modern world languages although do not bear any similarity with any other language, some western researches refer it to Ural-Altay language family $(1, \mathrm{p} 192)$.

In some researches there are thoughts about relationship of Sumerian language with the Caucasus, Tibet-Burma, Ural-Altay, as well as Turkic languages: "It can be thought that Sumerian people were founded at the result of mix of ethnos speaking in different languages, but out of these languages Sumerian prevailed, and became communication and graphic means." (2, p. 47).

Dr.Osman Nedim Tuna during his study in Istanbul University in 1947-1948 years began his researches on Sumerian language starting from "Eti Language dictionary" translated from Sturtevent's "Httite Glossary and Supplement to a Httite Glossary" by Munire B.Chelebi and wrote "The issue of the age of the Turkish language in accordance with the historical relationship of Sumerian and Turkic languages". Comparison of the Sumerian language with Azerbaijan language, especially with Nakhchivan group dialects in the above mentioned work and in the book "Sumerian is definitely a Turkic language" published in Istanbul by an Azerbaijan sumerologist Atakishi Jaliloghlu in 2011 at present time confirms the claims about Sumerian language to be a Turkic language.

Comparison of language facts about Sumerian language with Azerbaijan dialectic lexics both from phonetic and lexical aspects in the works of both authors confirms the Turkish language to be the most ancient language once again highlighting the historical development way of ancient Turkish language.

$\begin{array}{ll}\text { SUMERIAN LANGUAGE } & \text { NAKHCHIVAN DIALECT } \\ \text { in-jin } & \text { in-jin (someone) } \\ \text { kabkadak } & \text { qabqacaq (kitchen utensils) } \\ \text { azuk } & \text { azuqa (provisions) } \\ \text { di//ti } & \text { de(say) } \\ \text { neme } & \text { namana(what kind of) }\end{array}$

One of the most serious factors confirming this fact is related with the historical development of lexic units existing in ancient Sumerian in Turkic languages. Although accompanied with different sound transitions as $d>y, d>n, d>t, t>y, g>y, n>y, m>k, s>y, z>y, s ̧>s>c, z>c ̧$, besides Azerbaijan dialects they bear similar semantic load in other ancient Turkic monuments: dar//yar-yarma (to cut), dib//yip - ip(rope), dirig//irig - iri, sərt, kobud,(huge, hard, rough), taga//yăğ - düşmən (an enemy), tir//yir-yer, torpaq, yerüzü,(ground, the earth) tu//yu-yumaq (to wash), gișig//eșik-qapı,(a door) muşen//kuş-quş (a bird), nad//yad-yaymaq, döşəmək, ( to spread) nanga//yaya-yan torəf,(lateral side) nigin//yıgın-yı̆̆ın, toplanmış, yığılmış, (heap) ( nunuz//yinçü-inci (a pearl), nurum//yaruk-işıq, nur, parlaq,(light, shining) sig//yig-yey, yaxşı, çox yaxşı,(good, very well) silig//elig-al (a hand), sulu//yolyol, safar etmak (a way, to set off) (this word is used in Nakhchivan group dialects in the form of sülonmək ), sag//çăga-yeni doğulmuş, çağa,(newborn, baby), şulpael/çolpan- çolpan, yəni zöhrə ulduzu (Venus), zi(d)//çin- gerçək,(real) un//kun-xalq(nation) (It is used in Nakhchivan group of dialects in the form of el-gün), uru//koru-qorumaq (to protect), uşan//kuş-quş (a bird), uşub//kuş+eb-quş evi, yuva,( a bird nest), adakur//adak-ayaq, içki qadəhi, a wine glass, gid//id-iy, qoxu,(smell), kid//kıd-qly, qlymaq, öldürmək,(to kill), nad//yad-yaymaq (to spread), tugdu//tügündüyüm ( a knot) (In Nakhchivan group dialects is used in the variant düymok in the meaning of "to close"), izim-//isig-isti, (warm), şurum//sürüg-sürü, (a flock), dingir//tegri-tanrl, (God), azgul/asguasmaq,(to hang), du//to(l)-dolmaq, (to fill), tuku//toku - toxa,vur(to beat) (this word exists in Nakhchivan group of dialects as " toxmaq" - "a mallet"), eş//es-əsmək, (to blow) 
kabkagag//kabkacak-qabqaçaq(kitchen utensils), udi//udt- uyu, uyumaq, (to sleep) kaş//kaş-qaç, (to run), ki//kl-etmak, (to do), nammu//neme-na qadar,(how much) nig//ney-na, nasna,(what, something), nignamel/nemeniy-har şey, har no isa, (everything, anything) (it is used in Nakhchivan group of dialects in the form of "nomono"-"what kind of) (9, p.5-23).

As these appellative lexemes, animal names in Sumerian language attract attention as they exist in Nakhchivan, South Azerbaijan and Eastern Anatolia dialects with the same phonosemantic load. The word oğlaq meaning an animal name in Azerbaijan dialect lexics in ancient Sumerian language as kañadz+ak//kiñidz+ik as it is and in the form of $k \imath d l k / / k i d i k / / q i d i y h, \boldsymbol{k o n} \tilde{n} o d z+\boldsymbol{u k}$---qodux//koduk - eş̧̧ək balası, donkey cub, ḳuñudz+uk ---- quzu, a lamb, köñöts+ek ---- dəvə balası köş̧ək//köşsek, a camel cub, künüuts+ük - küçük, a puppy are used in Nakhchivan and Eastern Anatolia dialects $(9$, p.63; 7, p.192).

In some resources we come across the first alphabet referring to Sumerian i.e., cuneiform writings which were further used by Acadians and Elams, and at the same time there is information stating that graphical form of Ugartu and Persian languages were based on cuneiform writings of Sumerian language which does not include logographic signs (2, p.114). Although in recent researches there was much attempt to find the word of Indian-European origin in Sumerian language, much more similarities were found between the lexics of Sumerian and modern Turkic languages. According to the historians referring to these similar language facts, Sumerian is an ancient Turkish language. Although Sumerian language has common typological peculiarities with Altay languages, this theory has been put forward for the first time by a historian named Julius Oppert. M.I. Dyakonov approached to these different claims about ancient Sumerian language in quite different plain. He divided Front Asia languages into eight groups - Sumerian language, Elam language, Hitt language, Hurri and Urartu languages, Kartvel language, Indian -European languages, Northern-Eastern Caucasus languages and stated that none of these languages is related with Sumerian language (5, p.29). As many scholars M.I.Dyakonov in his researches told that according to morphological indicators, ancient Sumerian is an aqqultinative language as Turkic languages: " Sumerian, Elam, Hurri and Urartu languages refer to aqqultinative language type and in Sumerian language it is typical for each grammatical element to be expressed by a separate indicator, and these indicators are placed one after another in accordance with a certain sequence: the root of the word, the main word and suffixes" (5, p. 9).

Historical dialectological facts obtained from the comparative researches carried out according to both M.I.Dyakov's and other researchers' works show that ancient Sumerian language has a particular place among South group of dialects of Azerbaijan language, particularly, Nakhchivan, Southern Azerbaijan and Anatolia accents.

Working condition of a plenty of lexic units existing in the language of the ancient Turkish monuments, particularly, in Orkhon inscriptions, and in "Kitabi Dada Gorgud" sagas, as well as in "Ibn Muhanna's Dictionary", "Oghuzname”, M.Kashgarli’s "Divanu lughet-it turk" ("Turkish dictionary"), and at the same time in the folklore of the Turkic nations, in the classic literature written until the XIX century and in modern Turkic languages in Azerbaijan dialects as they were in the Sumerian language is one of the significant factors determining historical status of Azerbaijan language.

Taking into consideration grammatical peculiarities of Sumerian language stated by M.I.Dyankov, comparison of the dictionaries compiled on the basis of the Sumerian language with the dialects of Azerbaijan language confirms the claim about Sumerian language to be a Turkic language. Working condition of a number of lexic units in ancient Sumerian language in modern Turkic languages and Azerbaijan dialects from phonosemantic aspect are quite serious language factors determining historical status of Azerbaijan language. Comparison of the ancient Sumerian language with modern Turkic languages and dialects highlighting historical development of the Turkish language confirms the fact that modern Azerbaijan and Turkish language derived from ancient Sumerian language:

yağı-düşmən, (an enemy), yu-yumaq, (to wash), kul-qul,(a slave), ylğın-toplanmış, (a pile), yig-yeğ//yey, çă̆a-körpə,(a baby), çak-çaxmaq, vurmaq,(to strike), köğ̈̈s-köks,(breast), gid-gidi, fani,(temporary), yogun-yoğun, qalın, (thick) tügün-düyüm, bağlam,(a knot), çin-gerçək, doğru, (truth), eke-böyük qardaş, (an elder brother), üz-üzmək, kasmək, (to cut), süz-süzmək, ( to pour, to filter), tuş-

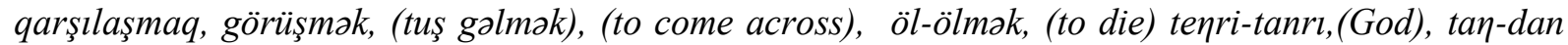
(sübh tezdən), (in the dawn), nen-aşya va ya har hansı bir nasna, ( a thing, or something), isigisti,(warm), azuk-azuqə,(provisions), sürüg-sürü, (a flock), asgu-asgl, (a hanger), asmaq,(to hang), kapkadak-qab-qacaq,(kitchen utensils) kaç-qaçmaq, (to run), kuru-yer, torpaq,(a land, an earth), 
neme-na qadar ),( nemene, look at:Nakhchivan dialect), korl-qorumaq, (to protect), toku-toxumaq, (to weive) toxa-vur,(tokhmag in Nakhchivan dialect) vurmaq, (to beat) (tokhmaq - in Nakhchivan dialect), togıra-doğra, ( to slice), dengüss-yersiz danışan, zavzək, ( garrulous), dingildo-oyna, (to

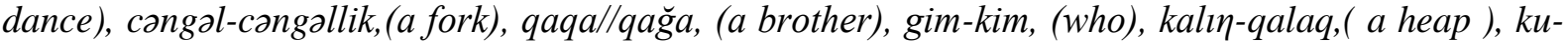
sas,(a sound), öbür-o biri ( another one).

Comparing similar language facts between the ancient Sumerian and Turkish languages the collaborators of the Uludagh University determined common language elements and it is one of the researches confirming this fact.

Table 1.

\begin{tabular}{|c|c|c|c|}
\hline IN SUMERIAN & $\begin{array}{l}\text { NAKHCHIVAN, SOUTH } \\
\text { AZERBAIJAN AND } \\
\text { ANATOLIA ACCENTS }\end{array}$ & $\begin{array}{l}\text { AZERBAIJAN } \\
\text { LANGUAGE ELI }\end{array}$ & $\begin{array}{c}\text { TURKEY } \\
\text { TURKISH İ }\end{array}$ \\
\hline Mu & $\mathrm{mu} / / \mathrm{ml} / / \mathrm{b} 1$, ol & bu, o (this, that) & $\begin{array}{l}\text { şu, bu, o (this, that, } \\
\text { it) }\end{array}$ \\
\hline Guruvaş & $\begin{array}{l}\text { qarabaş, garavaş, karavaş } \\
\text { a maidservant }\end{array}$ & $\begin{array}{l}\text { qul//kölə } \\
\text { a slave }\end{array}$ & $\begin{array}{l}\text { kadın köle } \\
\text { a maidservant }\end{array}$ \\
\hline Uș & üş, uş (three) & Üç (three) & Üç(three) \\
\hline Aur & aır//ağır (heavy) & ağır (heavy) & Ağır (heavy) \\
\hline San & san//say (number) & Say (number) & Say (number) \\
\hline Ikki & Iki (two) & Iki (two) & Iki (two) \\
\hline $\mathbf{U I}$ & oul//uul, olan//ulan (a son) & oğul (a son) & Oğul (a son) \\
\hline Er & ər//er//eren (a brave man) & or (a brave man) & Er (a brave man) \\
\hline Ud & od//ud (a fire) & od//atəș (a fire) & od//ateș (a fire) \\
\hline Asgu & asq1//asqu//asg1 (a hanger) & Asq1 (a hanger) & Ask1 (a hanger) \\
\hline Gu & qu (səs) (sound) & səs (sound) & Ses(sound) \\
\hline Duru & Duru (pure, clean) & $\begin{array}{l}\text { turu (təmiz) (pure, } \\
\text { clean) }\end{array}$ & Temiz (pure, clean) \\
\hline Um & um (ummaq) (to set hopes) & $\begin{array}{l}\text { istəmək, arzulamaq } \\
\text { (to wish) }\end{array}$ & $\begin{array}{l}\text { Istemek } \\
\text { (to wish) }\end{array}$ \\
\hline
\end{tabular}

The words as $\boldsymbol{u m}, \boldsymbol{q u}, \mathbf{m u} / / \mathbf{m} \boldsymbol{l}, \mathbf{s a n} / / \mathbf{s a y}$ which existed in ancient Sumerian language and which are no more used in Azerbaijan literary language, are now used only in dialects of Azerbaijan language, particularly in ancient Azerbaijan folklore samples and this is the most serious language fact confirming Sumerian being a Turkic language: For example:

Məsələn, Umduğun yerdən küsəllər. (One will feel hurt from someone on whom he set hopes.). $\boldsymbol{Q u}$ vursan qulaq tutular... (If you will make a sound, the ears will hurt). Allah adamı minnan betərinnən saxlasın (Nax.). (Let God bless us from worse than it, (Nakhchivan ). "Ağamın bir donu var, qatlamaq olmaz, İçi dolu ağ abbası, sanamaq olmaz, İçində bir manat var" "My lord has a gown which cannot be folded, it is full of white coins, but it cannot be counted, it has a manat in it" besides this kind of spoken language and folklore samples, in modern Azerbaijan written literary samples the traces of ancient Sumerian language are clearly seen. Umdum nə verdi ki, küsam nə verə, Man bela dünyanın nəyindon küsüm? (M.Araz.) (What my hope has given to me, and what it will give me if I take hurt on it, What sense it will do if I take umbrage of this world?) (M.Araz).

Although comparison of the Sumerian language with modern Turkic languages is not an easy work, but it is, generally, of great significance from the point of studying phonosemantic changes taking place in different stages of historical development of the Turkish language. For this purpose, first of all, sound transitions and different phonovariants of these sounds in phonetic structure of the Sumerian and modern Turkic languages and dialects should be paid attention. Prof.F.Jalilov writes about significance of comparison of Front Asia izogoloses in Azerbaijan language from the point of view of relations between ancient languages: "If Urartu- Praazerbaijan relations have been reflected in the language parallels in the documents referring to the IX-VII centuries B.C., then the history of Sumerian-praazerbaijan, Acadianpraazerbaijan, khatt/khett- praazerbaijan parallels goes up to the beginning of the II millennium" $(11, \mathrm{p} .38)$. While speaking about initial prolongation of vowels in modern Turkic languages and dialects, turkologists show two types of vowels according to this prolongation: 1. Initial prolongation; .2. Final prolongation (5, p.13). Although turkologists show that for modern period the final prolongation is typical for modern Turkic 
languages and dialects, they say that initial prolongation is typical for ancient periods of Turkic languages, but they could not explain fully the reason and source of it. Parallel language factor found out during comparison of Azerbaijan dialects with ancient Sumerian language lay ground for solution of this problem.

Dialectological researches show that one of the main reasons of the initial prolongation in Azerbaijan dialects is drop of some sounds in the word, and it is a phonetic peculiarity of Sumerian language. Drop of consonants in Nakhchivan group accents of Azerbaijan language $\boldsymbol{q}, \boldsymbol{k}, \boldsymbol{d}, \boldsymbol{h}, \boldsymbol{v}, \boldsymbol{m}, \boldsymbol{n}, \boldsymbol{y}, \boldsymbol{p}$,

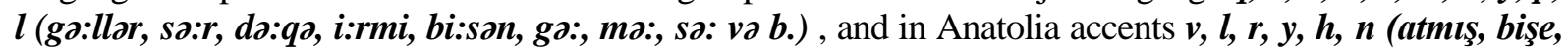
töbe, həbs vo b.) causes initial prolongation and we see its first traces in ancient Sumerian language.

The traces of initial prolongation in Nakhchivan group of accents are observed mostly in personal pronouns just as in Sumerian language. In the researches of K.Imamguliyev existence of this prolongation in the first and second person singular in Sharur region accent just as in ancient Sumerian language was noted in the form of $\boldsymbol{m o :} / / \boldsymbol{m} \overline{\boldsymbol{a}} \mathbf{s} \boldsymbol{s}: / / \mathbf{s} \overline{\boldsymbol{a}}(12, \mathrm{p} .17)$.

$\begin{array}{lcc}\text { In Sumerian } & \text { Nakhchivan } & \text { Anatolia } \\ \mathrm{me} \text { (mən) (I) } & \mathrm{mē} / / \mathrm{m}: / / \mathrm{ma} & \text { ben } \\ \mathrm{mu} \text { (bu) (this) } & \mathrm{m} / / \mathrm{b} 1 & \mathrm{~m} 1 \\ \mathrm{ul} \text { (oğlan) (a boy) } & \overline{\text { ollan }} & \text { ulan }\end{array}$

Osman Nnedim Tuna showed that the reason of emergence of alternat sounds as $\boldsymbol{a}-\boldsymbol{e}, \boldsymbol{e}-\boldsymbol{i}, \boldsymbol{b}-\boldsymbol{p}$, $\boldsymbol{d}-\boldsymbol{t}, \boldsymbol{g}-\boldsymbol{k}, \boldsymbol{b}-\boldsymbol{m}, \boldsymbol{m}-\boldsymbol{n}, \boldsymbol{z}-\boldsymbol{s}-\boldsymbol{s}$ in reading of Sumerian words and in phonetic system of Sumerian language were detected via Sami languages: ab//eb//ib//e -ev; home, tag-te(ga) değmek; (to touch), dar//tar yarmak; (to cut), siș//şiş//şeş - asıl bir xanım,(a noble woman), sar//şar - yazmak,(to write), sur//şur yoz, azak//asig//aşig - ruh xastaliyi,(mental illness), gurun//kurun - meyva,(fruit), dilib - dilim (a slice $)(9$, p.35). These sound transitions existing in ancient Sumerian in a modern stage show themselves in Nakhchivan and Anatolia accents and as one of the typical peculiarity of Turkic languages. In comparison of Nakhchivan, South Azerbaijan and Eastern Anatolia dialects and accents with Sumerian language, sound variants as $\boldsymbol{b}>\boldsymbol{v}, \boldsymbol{z}<\boldsymbol{d} />\boldsymbol{y}, \boldsymbol{g}>\breve{g}, \boldsymbol{n}<\tilde{\boldsymbol{n}}>\boldsymbol{n} \boldsymbol{y}, \boldsymbol{y}>\boldsymbol{n}, \boldsymbol{y}$ were detected in all modern Turkic languages and dialects beginning from ancient Turkish language.

One of the phonetic peculiarities of Nakhchivan, South Azerbaijan and Anatolia accents parallel to Sumerian language is existence of diphtongs. The first samples of diphthongs in Azerbaijan and Anatolia accents emerged at the result of sound are met namely in ancient Sumerian language: aur - ağır, (heavy), şulpae - çolpan ylldızl, yəni zöhrə ulduzu,(Venus), mae - mənə,(to me), zae - sənə,(to you), ulia//öley sulu yer, bataqliq (wetland, marsh). One of the most serious facts confirming Sumerian language to be more close to Turkish language is that it has the same morphological indicators as the Turkish language:

1. As in modern Turkic languages in ancient Sumerian language also new word formation is based on stem+morphem model, i.e. in Sumerian language also as in Turkish the new words are formed by adding suffixes to the word stem.

2. Ancient Sumerian language is very rich from the point of view of verbs just as modern Turkish language.

3. There is a sound harmony.

4. In ancient Sumerian language there is no gender category as in modern Turkic languages.

5. As in modern Turkic languages in ancient Sumerian language also sometimes the concept of majority is conveyed by repeating the words, i.e., in a syntactic way.

6. As in modern Turkic languages in ancient Sumerian language also some words are used both as nouns and verbs:

I. 1. iç-içəri, (in)

II. 1. düz-düzan, hamar yol;(smooth way, a plain)

III.1. bar - var-dövlat; (wealth)

2. iç-içmək;(to drink)

2. düz-düzmək;(to arrange)

2. bar-var barmaq, getmək. (to go)

-q və -k suffixes in modern Azerbaijan language forming nouns from verbs were active in ancient Sumerian language also and this grammatical peculiarity is still alive in Nakhchivan and Anatolia accents: $\ddot{u} t \ddot{i}-\boldsymbol{k}$ - $\ddot{u} t \ddot{u} \boldsymbol{k}, \boldsymbol{u d u}-\boldsymbol{q}, \boldsymbol{u z u n}-\boldsymbol{u z u} \boldsymbol{k}$. The nouns, adjectives and numerals in ancient Sumerian language are similar with Azerbaijan and Turkey Turkish languages according to grammar compliance. I.T.Kanaeva in her researches confirms similarity of the numerals in Sumerian language with those in Turkic languages according to their structure and she shows that in Sumerian language ordinal numerals derived from cardinal numerals (10, p. 46-52). The fact that the numerals in ancient Sumerian language share the common peculiarities with those in Nakhchivan, South Azerbaijan and Anatolia accents confirms this thought once again: uş, un (in Sumerian); üş, uş, un (in Nakhchivan, South Azerbaijan and Anatolia 
accents); $\ddot{u} \boldsymbol{c}, \boldsymbol{o n}$ (Azerbaijan and Turkey Turkish). The fact that pronouns used in Nakhchivan and Anatolia accents during 6000 years- history are used in the way as they were used in ancient Sumerian language is also one of the language peculiarities attracting attention. Ancient Sumrian interrogative pronoun nəmə is being used in Nakhchivan and Anatolia accents in the form of nemənə - nə qədər.

Table 2.

\begin{tabular}{|l|l|l|l|l|l|l|l|l|l|l|}
\hline Turkey & Azerbaijan & Turkmen & Uzbek & $\begin{array}{l}\text { New } \\
\text { Uyghur }\end{array}$ & Bashkir & Tatar & Kazak & Kirgiz & Yakut & Chuvash \\
\hline O & O & ol & U & U & Ul & ul & Ol & al & kini & văl / ul \\
\hline Ona & Ona & oňa & unga & uningha & Uğa & aña & Oğan & aga & kiniexe & Ăna \\
\hline Onu & Onu & onu & Uni & Uni & Unı & anı & Onı & anı & kinini & Ăna \\
\hline Onda & Onda & onda & unda & $\begin{array}{l}\text { unda / } \\
\text { uningda } \\
\text { / anda }\end{array}$ & unda & anda & Onda & anda & - & $\begin{array}{l}\text { unra / } \\
\text { unta }\end{array}$ \\
\hline ondan & Ondan & ondan & undan & $\begin{array}{l}\text { undin / } \\
\text { uningdin } \\
\text { / andin }\end{array}$ & undan & annan & Onan & andan & kinitten & $\begin{array}{l}\text { unran / } \\
\text { untan }\end{array}$ \\
\hline Onun & Onun & onuň & uning & uning & Unıñ & anıñ & Onıñ & anın & kiene & un / unăn \\
\hline
\end{tabular}

Besides historical and geographical facts confirming Nakhchivan, South Azerbaijan and Anatolia accents sharing the same peculiarities with the ancient Sumerian language from phonomorphological point of view, it also needs presentation of ethnogenetic factors as a very serious historical fact. Prof. Dr. Muazzez Ilmiye Chighin referring to Servet Somunjuoghlu's "From Siberia to Anatolia the Turks on the Rock" says that the ethnogeny of the Sumerians goes to the most ancient Turkic tribe kengerlers and that they called themselves lu.kenger.ra - Kengerli insan" (Kengerli man) "Kiengir, Kingir, Kenger".

Besides it, one of the facts confirming the researchers' thoughts is that the Sumerians named the first city they established in Mesopotamia Kengerli. Moreover, in Turkmenistan one of Turkmen regions is called "Kugur" and one of the place names in Azerbaijan is "Kenger" and this have been substantiated on the basis of historical facts 14 .

These historical linguistic facts show the traces of ancient Sumerian language in Nakhchivan and Anatolia accents, as well as in a number of Turkic languages. As it seems from the researches, the fact that the traces of the ancient Sumerian language lives mostly in dialects ad accents, rather than in literary language shows the scale of significance of dialectological researches in linguistic investigations. Direct relation of Sumerian language with Nakhchivan and Anatolia accents is a fact indicating that Sumerian is the most ancient Turkic language; at the same time it shows that modern Nakhchivan, South Azerbaijan and Eastern Anatolia accents have 6000 years-history. These all are linguistic facts.

\section{REFERENCES}

1. Amanjolov A.S. History of Ancient Turkic Script, Almaty, 2003.

2. Thomas Walter Manson/ A companion to the Bible/ T\&T/Clark, 1950.

3. Y.B.Yusifov. History of ancient East. Baku State University Publishing House, 1993.

4. Ekrem Akkurgal. The Hattian and Hittite civilizations. Ministry of Culture, 2001.

5. İ.M.Dyakonov. Languages of ancient Front Asia. Moscow,1967.

6. Atakichi Jeliloghlu Kasim, "Sumerian is definitely a Turkic language. Istanbul, 2001

7. Ahmet Buran, Sherife Oghrash. Elazıx Ağızları. Elazıgh, 2003.

8. Dialects and accents of Nakhchivan AR. Baku, 1962.

9. Osman Nedim Tuna. The age of Turkish language in historical relationship of Sumerian and Turkic languages, Ankara, 1990

10. İ.T.Kaneva. Sumerian language. Sankt-Peterburg, 1996.

11. Jalilov F. Morphonlogy of Azerbaijan language. Baku, 1988.

12. Imamguliyeva K. Sharur accents of Azerbaijan language. Dissertation for candidacy. Baku, 1991.

13. Muazzez İlmiye Çıgh. Storm in Sumerians, Turks in Storm. Source publications 2008.

14. http://onturk.wordpress.com/2011/04/27/sumer-dili-ile-turk-dili-karsilastirmalari/ 